\title{
PELAKSANAAN PERJANJIAN SERTA PERLINDUNGAN HUKUM PRAKTEK BISNIS WARALABA DI INDONESIA
}

\author{
Dwi Atmoko \\ Universitas Bhayangkara Jakarta Raya \\ dwi.atmoko1976@gmail.com
}

\begin{tabular}{|c|c|c|}
\hline Naskah diterima: & Revisi: & Naskah disetujui: \\
$28 / 4 / 2019$ & $20 / 5 / 2019$ & $20 / 5 / 2019$ \\
\hline
\end{tabular}

\begin{abstract}
Abstrak
Di Indonesia aturan hukum mengenai Waralaba (Franchise) belum lengkap. Indikator hal ini dapat kita cermati dari ketentuan hukum yang mengatur bisnis waralaba, yang sampai saat ini baru diatur dalam satu (1) Peraturan Pemerintah dan satu (1) Peraturan Menteri, sebagaimana disebut di atas. Pengaturan melalui undang-undang belum tersentuh oleh pemerintah. Memang ada peraturan dari Departemen teknis yang bersangkutan, namun pengaturan ini sama sekali belum memadai mengingat bisnis melalui sistem waralaba ini selalu berkembang secara dinamis sesuai perkembangan dunia usaha, dan membentuk model-model baru dalam prakteknya.Padahal kalau terjadi sesuatu yang menyangkut perjanjian, maka para pihak memerlukan pranata hukum yang komperhensif sebagai panduan atau guide lines baik pra pembuatan perjanjian maupun pasca perjanjian. Hal ini diperlukan untuk menghindari pemegang dan penerima waralaba dari kerugian yang tidak diinginkan karena belum lengkapnya perangkat hukum yang melindungi kepentingan para pihak. Selain itu dalam tulisan ini untuk mengetahui bagaimana mekanisme dan proses pelaksanaan perjanjian waralaba dalam praktek dalam rangka pengembangan kerja sama bisnis yang saling menguntungkan serta untuk mengetahui perlindungan hukum bagi para pihak dalam pelaksanaan perjanjian waralaba.Pada dasarnya untuk perjanjian berlaku umum sebagaimana di atur dipasal $1320 \mathrm{KUH}$ Perdata, yaitu perjanjian harus dilakukan dengan itikad baik, tidak boleh bertentangan dengan kebiasaan yang berlaku, harus dilakukan berdasarkan asas kepatutan dan tidak boleh melanggar kepentingan umum, akan tetapi lebih khususnya diatur pada Peraturan Pemerintah Nomor 42 Tahun 2007 Tentang Waralaba. Selanjutnya dalam rangka perlindungan hukum terhadap para pihak dalam perjanjian waralaba dalam Peraturan Pemerintah Nomor 42Tahun 2007 , terdapat beberapa konsep perlindungan hukum terhadap usaha waralaba, yaitu:Pasal 3 huruf f yang menyebutkan bahwa waralaba harus merupakan suatu hak kekayaan intelektual yang sudah terdaftar sehingga terdapat kepastian hukum dalam bisinis waralaba serta menghilangkan keraguraguan akan waralaba yang ditawarkan.
\end{abstract}

Kata Kunci : Waralaba, Pelaksanaan Perjanjian, Perlindungan Pihak Penerima

\begin{abstract}
In Indonesia, the legal rules regarding Franchises are not yet complete. We can observe this indicator from the legal provisions governing the franchise business, which until now have only been regulated in one (1) Government Regulation and one (1) Ministerial Regulation,
\end{abstract}


as mentioned above. Regulations through legislation have not been touched by the government. Indeed, there are regulations from the technical department in question, but this arrangement is not at all sufficient considering that the business through this franchise system always develops dynamically according to the development of the business world, and forms new models in practice. parties need comprehensive legal institutions as a guide or guide lines for both pre-agreement and post-agreement arrangements. This is necessary to avoid franchise holders and recipients from unwanted losses due to incomplete legal instruments that protect the interests of the parties. Besides this in this paper to find out how the mechanism and process of implementing franchise agreements in practice in the framework of developing mutually beneficial business cooperation and to find out legal protection for the parties in the implementation of franchise agreements. Basically for general agreements as set forth in 1320 KUH Civil Code, i.e. an agreement must be carried out in good faith, may not conflict with prevailing habits, must be carried out based on propriety principles and may not violate public interests, but more specifically regulated in Government Regulation Number 42 of 2007 concerning Franchising. Furthermore, in the framework of legal protection against the parties in the franchise agreement in Government Regulation Number 42 of 2007, there are several legal protection concepts for franchising, namely: Article 3 letter $f$ which states that franchises must be registered intellectual property so that there is legal certainty in the franchise business and eliminate the doubts about the franchise offered.

Keywords: Franchise, Implementation of Agreement, Protection of Recipient Parties.

\section{PENDAHULUAN}

Dalam dunia usaha yang selalu bergerak dinamis, pelaku usaha selalu mencari terobosan-terobosan baru dalam mengembangkan usahanya.Hal ini semakin terasa di era global saat ini di mana ekspansi dunia bisnis telah menembus batas ruang, waktu dan teritorial suatu negara. Salah satu terobosan yang dilakukan oleh pelaku bisnis adalah pengembangan usaha melalui sistem franchise yang di Indonesia diistilahkan dengan waralaba. Sistem ini bagi sebagian usahawan yang ingin mengembangkan usahanya dipandang efektif dan tepat guna dalam pengembangan suatu perusahaan karena tidak membutuhkan investasi langsung melainkan melibatkan kerja sama pihak lain. Munculnya bisnis waralaba tentu membawa suatu konsekuensi logis terhadap dunia hukum, diperlukan pranata hukum yang memadai untuk mengatur bisnis tersebut di suatu negara, demi terciptanya kepastian dan perlindungan hukum bagi para pihak yang terlibat dalam bisnis ini.

Dengan kemampuan teknologi dan pengetahuan atau penemuan yang spesifik, dan biasanya sedikit lebih maju atau inovatif, pengusaha dapat menawarkan kelebihan kemampuan yang dimiliki perusahaanya kepada pihak lain untuk menjalankan usahanya. Ternyata pemberian izin penggunaan teknologi dan atau pengetahuan itu saja dalam banyak 
hal masih dirasakan kurang cukup oleh kalangan usahawan, khususnya bagi mereka yang berorientasi internasional. Usahawan merasakan perlunya suatu bentuk "penyeragaman total", agar masyarakat konsumen dapat mengenal produk yang dihasilkan atau dijual olehnya secara luas, sehingga maksud pengembangan usaha yang ingin dicapai olehnya dapat terwujud dan kemudian terjadilah bentuk-bentuk lisensi seperti yang kita kenal dewasa ini, yang bersifat komprehensif. ${ }^{1}$

Perkembangan dunia usaha ternyata tidak berhenti sampai disitu, usahawan kemudian tidak hanya berbicara soal keseragaman dalam bentuk Hak atas Kekayaan Intelektual yang dilisensikan, tetapi juga kewajiban-kewajiban untuk mematuhi dan menjalankan segala dan setiap perintah yang dikeluarkan, termasuk sistem pelaksanaan operasional kegiatan yang diberikan lisensi tersebut. Untuk itu maka mulai dikembangkanlah franchise (Waralaba) sebagai alternatif pengembangan usaha, khususnya yang dilakukan secara internasional. Sebagaimana halnya pemberian lisensi, waralaba inipun sesungguhnya mengandalkan para kemampuan mitra usaha dalam mengembangkan dan menjalankan kegiata usaha waralaba melalui tata cara, proses serta suatu aturan dan yang telah ditentukan oleh pengusaha pemberi waralaba. Dalam waralaba ini, sebagaimana halnya lisensi dapat dikatakan, sebagai bagian dari kepatuhan mitra usaha terhadap aturan main yang diberikan oleh pengusaha pemberi waralaba, mitra usaha diberikan hak untuk memanfaatkan Hak atas Kekayaan Intelektual dan sistem kegiatan operasional dari pengusaha pemberi waralaba, baik dalam bentuk penggunaan merek dagang, merek jasa, hak cipta atas logo, desain industri, paten berupa teknologi, maupun rahasia dagang. Pengusaha pemberi waralaba selanjutnya memperoleh imbalan royalty atas penggunaan Hak atas Kekayaan Intelektual dan sistem kegiatan operasional mereka oleh penerima waralaba.

Demikian dapat kita lihat bahwa ternyata waralaba juga dapat dipakai sebagai sarana pengembangan usaha secara tanpa batas ke seluruh bagian dunia. Ini berarti seorang pemberi waralaba harus mengetahui secara pasti ketentuan-ketentuan hukum yang berlaku di negara dimana waralaba akan diberikan atau dikembangkan, agar nantinya penerima waralaba tidak beralih "wujud" dari mitra usaha menjadi kompetitor. ${ }^{2}$

Franchise atau waralaba dalam praktek dunia bisnis telah cukup lama dikenal secara internasional. Meskipun secara yuridis baru diatur di Indonesia pada tahun 1997 dengan dikeluarkannya Peraturan Pemerintah RI No. 16 Tahun 1997 tanggal 18 Juni 1997 tentang

\footnotetext{
1 Gunawan Widjaya, Waralaba, Rajawali Pers, Jakarta, 2001, hal. 3.

2 Widjaya, Gunawan. Lisensi atau Waralaba, Suatu Panduan Praktis, Raja Grafindo Persada, Jakarta, 2002.hal. 4-5.
} 
Waralaba, dan Keputusan Menteri Perindustrian dan Perdagangan Republik Indonesia Nomor 259/MPP/Kep/7/1997 tanggal 30 Juli 1997 tentang Ketentuan dan Tata Cara Pelaksanaan Pendaftaran Usaha Waralaba. Dan Kemudian telah dirubah dengan Peraturan Pemerintah RI No. 42 Tahun 2007, serta Peraturan Menteri Perdagangan Republik Indonesia Nomor: 31/MDAG/PER/8/2008 tentang Penyelenggaraan Waralaba.

Waralaba sebagai suatu bentuk pengembangan usaha telah mendapat perhatian dari para pengusaha yang bermaksud mengembangkan usahanya secara internasional dapat melakukan beberapa macam pilihan cara, dari yang paling sederhana hingga yang paling kompleks. Secara singkat dikatakan oleh Keegen dalam Gunawan Wijaya bahwa ada lima macam cara pengembangan usaha, yaitu $:^{3}$

1. Melalui perdagangan internasional dengan cara ekspor impor;

2. Dengan pemberian lisensi;

3. Melakukan franchising (pemberian waralaba);

4. Membentuk perusahaan patungan

5. Melakukan penanaman modal langsung dengan kepemilikan yang menyeluruh, atau melalui merger, konsolidasi maupun akuisisi.

Dalam Peraturan Pemerintah RI No. 16 Tahun 1997 tanggal 18 Juni 1997 tentang Waralaba dikatakan bahwa : "Waralaba adalah perikatan dimana salah satu pihak diberikan hak untuk memanfaatkan dan atau menggunakan hak atas kekayaan intelektual atau penemuan atau ciri khas usaha yang dimiliki pihak lain dengan suatu imbalan berdasarkan persyaratan dan atau penjualan barang dan atau jasa. ${ }^{4}$

Sedangkan Peraturan Pemerintah RI No. 42 Tahun 2007 tentang Waralaba memberikan defenisi Waralaba adalah: Hak khusus yang dimiliki oleh orang perseorangan atau badan usaha terhadap sistem bisnis dengan ciri khas usaha dalam rangka memasarkan barang dan/atau jasa yang telah terbukti berhasil dan dapat dimanfaatkan dan/atau digunakan oleh pihak lain berdasarkan perjanjian waralaba. ${ }^{5}$

Sejak satu dekade terakhir, bisnis waralaba sangat marak di Indonesia. Banyak perusahaan dan industri, seperti makanan, salon, bengkel, apotik, pendidikan dan sebagainya dikembangkan melalui sistem yang disebut dengan istilah waralaba ini. Peluang bisnis ini sendiri sangat terbuka lebar mengingat kalangan pemilik waralaba selalu membantu

\footnotetext{
${ }^{3}$ Ibid, hal. 1.

${ }^{4}$ Republik Indonesia, Peraturan Pemerintah No. 16 Tahun 1997 tanggal 18 Juni 1997 tentang Waralaba, Pasal 1 angka 1.

${ }^{5}$ Peraturan Pemerintah RI No. 42 Tahun 2007 tentang Waralaba
} 
pengembangan pemegang hak waralabanya dengan berbagai cara. Pewaralaba lokal pun bermunculan ikut serta meramaikan persaingan bisnis waralaba. Hal ini menunjukan waralaba diminati oleh para pelaku bisnis dalam pengembangan usahanya.

Waralaba dalam dunia perdagangan merupakan salah satu sistem yang dianggap sangat menguntungkan ini telah dibuktikan oleh berbagai perusahaan nasional maupun perusahaan berkaliber internasional. Di Indonesia aturan hukum mengenai Waralaba (Franchise) belum lengkap. Indikator hal ini dapat kita cermati dari ketentuan hukum yang mengatur bisnis waralaba, yang sampai saat ini baru diatur dalam satu (1) Peraturan Pemerintah dan satu (1) Peraturan Menteri, sebagaimana disebut di atas. Pengaturan melalui undang-undang belum tersentuh oleh pemerintah. Memang ada peraturan dari Departemen teknis yang bersangkutan, namun pengaturan ini sama sekali belum memadai mengingat bisnis melalui sistem waralaba ini selalu berkembang secara dinamis sesuai perkembangan dunia usaha, dan membentuk model-model baru dalam prakteknya.

Padahal kalau terjadi sesuatu yang menyangkut perjanjian mereka, maka para pihak memerlukan pranata hukum yang komperhensif sebagai panduan atau guide lines baik pra pembuatan perjanjian maupun pasca perjanjian. Hal ini diperlukan untuk menghindari pemegang dan penerima waralaba dari kerugian yang tidak diinginkan karena belum lengkapnya perangkat hukum yang melindungi mereka.Oleh karena itu pengaturan tentang waralaba bagi para pihak yang akan menjalankan usahanya sangat ditentukan oleh perjanjian waralaba itu sendiri yang dibuat oleh kedua belah pihak. Pembuatan suatu kontrak bisnis merupakan momentum terpenting dalam suatu proses kerja sama bisnis mengingat dalam kontrak tersebut akan dituangkan segala sesuatu yang menyangkut penyelenggaraan kerja sama dan menjadi undang-undang bagi para pihak yang membuatnya.

Secara umum, yang di maksud dengan perjanjian franchise adalah pemberian hak oleh franchisor kepada franchisee untuk menggunakan kekhasan usaha atau cirri pengenal bisnis dibidang perdagangan atau jasa berupa jenis produk dan bentuk di usahakan termasuk identitas perusahaan (logo,merek, dan desain perusahaan, penggunaan rencana pemasaran serta pemberian bantuan yang luas, waktu, saat, jam operasional, pakaian, dan penampilan karyawan) sehingga kekhasan usaha atau cirri pengenal bisnis dagang dan jasa milik franchisee sama dengan kekhasan usaha atau bisnis dagang atau jasa milk dagang franshisor. ${ }^{6}$

\footnotetext{
${ }^{6}$ www.santoslolowang.com, 6 Maret 2011
} 
Dari kedua pengertian di atas ada dua pihak dalam perjanjian waralaba ini, Yaitu pemberi waralaba (franchisor) dan penerima waralaba (franchisee). Yang dimaksud dengan franchisor adalah pihak atau para pihak yang memberikan izin kepada pihak lain (franchisee) untuk menggunakan kekhasan usaha dan spesifikasi (ciri pengenal) bisnis miliknya. Sedangkan yang dimaksud dengan franchicee adalah pihak atau para pihak yang mendapat izin atau lisensi waralaba dari pihak franchisor untuk menggunakan kekhasan usaha atau spesifikasi usaha franchisor tersebut. Pada dasarnya franchicee adalah sebuah perjanjian mengenai metode pendistribusian barang dan jasa kepada konsumen. Franchisor dalam jangka waktu tertentu memberikan lisensi kepada franchisee untuk melakukan usaha pendistribusian barang dan jasa atas nama franchisor. ${ }^{7}$ Dalam perumusan dan pembuatan suatu kontrak masyarakat diberikan kebebasan oleh undang-undang untuk menentukan materi perjanjian dan dengan siapa mereka akan saling mengikatkan diri dalam suatu perjanjian sepanjang tidak bertentangan dengan syarat sah perjanjian sebagaimana dimaksud dalam Pasal 1320 KUHPerdata. Perjanjian yang dibuat tersebut mempunyai kekuatan mengikat sebagai undang-undang bagi kedua pihak. Asas kebebasan berkontrak bukan berarti tanpa pembatasan dalam perkembangannya telah terdapat campur tangan pemerintah dalam suatu perjanjian yang akan diselenggarakan. Dalam perjanjian waralaba pembatasan tersebut dapat dilihat dari kewajiban para pihak untuk mencantumkan klausula-klausula tertentu dalam perjanjian yang dibuatnya. Hal ini dimaksudkan oleh pembentuk undangundang untuk memberikan perlindungan hukum. Pembatasan lainnya dalam kebebasan berkontrak adalah dengan munculnya bentuk kontrak-kontrak standard atau baku.

Perjanjian baku adalah perjanjian yang ditentukan secara apriori oleh salah satu pihak. Dengan demikian isi perjanjiannya hanya ditentukan oleh salah satu pihak saja. Pihak lainnya hanya dapat memilih untuk menerima atau menolak perjanjian tersebut tanpa ikut menentukan isinya.Selanjutnya menurut Badrulzaman, asas kebebasan berkontrak tidak berarti tidak terbatas akan tetapi terbatas oleh tanggungjawab para pihak, sehingga kebebasan berkontrak sebagai asas diberi sifat yang bertangung jawab. Asas ini mendukung kedudukan yang seimbang di antara para pihak sehingga sebuah kontrak akan bersifat stabil dan memberikan keuntungan bagi kedua pihak. ${ }^{8}$

Hukum pada dasarnya adalah untuk perlindungan kepentingan manusia. Dalam setiap hubungan hukum, termasuk perjanjian harus ada keseimbangan antara para pihak supaya tidak terjadi konflik kepentingan. Namun dalam realitasnya tidak selalu demikian.

\footnotetext{
${ }^{7}$ Ibid

${ }^{8}$ Mariam D. Badrulzaman, Aneka Hukum Bisnis, Bandung, Alumni, 1994, hal. 45.
} 
Selalu terdapat kemungkinan salah satu pihak mempunyai posisi yang lebih kuat baik dari sisi ekonomis maupun dari penguasaan tehnologi atau suatu penemuan yang spesifik. Dalam kondisi ini salah satu pihak lebih mempunyai peluang untuk lebih diuntungkan dalam suatu perjanjian. Seringkali pihak penyusun menentukan syarat-syarat yang cukup memberatkan apalagi kontrak tersebut disajikan dalam bentuk kontrak standard, karena ketentuanketentuan dalam perjanjian dapat dipakai untuk mengantisipasi kemungkinan terjadinya kerugian pada pihaknya. Dalam hal demikian salah satu pihak hanya punya pilihan untuk menerima atau menolak perjanjian tersebut. ${ }^{9}$

Kerja sama bisnis yang saling menguntungkan dalam system waralaba merupakan suatu kebutuhan karena baik pemberi maupun penerima waralaba mempunyai kepentingan yang sama untuk mengembangkan usahanya dalam suatu kerangka sistem yang terpadu dan terkait satu sama lain. Dalam merealisasikan hal tersebut penyusunan dan pembuatan perjanjian waralaba secara seimbang antara para pihak sebagai dasar pelaksanaan kerja sama menjadi hal yang menarik untuk dikaji lebih lanjut.

Pada dasarnya setiap perikatan, termasuk perjanjian waralaba memiliki jangka waktu berlakunya, dan akan berakhir dengan sendirinya dengan habisnya jangka waktu pemberian waralaba yang diatur dalam perjanjian pemberian waralaba, kecuali jika diperpanjang atau diperbaharui oleh para pihak. Dalam Keputusan Menteri Perindustrian dan Perdagangan No. 259/MPP/KEP/1997 Pasal 8 yang mengatur waralaba disebutkan bahwa jangka waktu perjanjian waralaba ditentukan berlaku sekurang-kurangnya 5 (lima) tahun.

Perkembangan bisnis waralaba yang semakin marak dan kompleks dalam prakteknya telah memunculkan fenomena-fenomena baru baik dari aspek ekonomi maupun hukum khususnya yang menghendaki adanya pengaturan yang lebih komprehensif untuk terciptanya kepastian hukum, perlindungan hukum dan kerja sama yang saling menguntungkan.

Berdasarkan hal tersebut maka timbul beberapa permasalahan yaitu :

1. Bagaimana pelaksanaan perjanjian waralaba dalam praktek bisnis di Indonesia?

2. Sejauh mana perlindungan hukum bagi para pihak dalam pelaksanaan perjanjian waralaba.?

Berdasarkan perumusan masalah diatas, maka metode pendekatan yang digunakan dengan melalui empiris yuridis dengan pendekatan metode kualitatif. Metode ini digunakan karena beberapa pertimbangan yaitu: pertama, menyesuaikan metode ini lebih mudah

\footnotetext{
${ }^{9}$ Ibid, hal 46
} 
apabila berhadapan dengan kenyataan yang ada,; kedua, metode ini lebih peka dan lebih dapat menyesuaikan diri dengan banyak penajaman pengaruh bersama terhadap pola-pola nilai yang dihadapi.

\section{PEMBAHASAN}

\section{A. Pengertian Perjanjian Pada Umumnya}

Dalam lapangan kehidupan sehari-hari seringkali dipergunakan istilah perjanjian, meskipun hanya dibuat secara lisan saja,tetapi di dalam dunia usaha, perjanjian adalah suatu hal yang sangat penting karena menyangkut bidang usaha yang digeluti. Mengingat akan hal tersebut, dalam hukum perjanjian merupakan suatu bentuk manifestasi adanya kepastian hukum. Oleh karena itu hendaknya setiap perjanjian dibuat secara tertulis agar diperoleh suatu kekuatan hukum, sehingga tujuan kepastian hukum dapat terwujud. Sehubungan dengan perjanjian Pasal 1313 KUH Perdata memberikan definisi sebagai berikut: "Suatu perjanjian adalah suatu perbuatan dengan mana satu orang atau lebih mengikatkan dirinya terhadap satu orang lain atau lebih".

Menurut R. Setiawan, definisi tersebut kurang lengkap, karena hanya menyebutkan persetujuan sepihak saja dan juga sangat luas karena dengan dipergunakannya perkataan “perbuatan" tercakup juga perwakilan sukarela dan perbuatan melawan hukum. Beliau memberikan definisi tersebut : 1). Perbuatan harus diartikan sebagai perbuatan hukum yaitu perbuatan yang bertujuan untuk menimbulkan akibat hukum, 2). Menambahkan perkataan "atau saling mengikatkan dirinya" dalam Pasal 1313 KUHPerdata. ${ }^{10}$ Sehingga menurut beliau perumusannya menjadi perjanjian adalah suatu perbuatan hukum, dimanasatu orang atau lebih mengikatkan dirinya terhadap satu orang atau lebih. Menurut RUTTEN, rumusan perjanjian menurut Pasal 1313 KUH Perdata tersebut terlalu luas dan mengandung beberapa kelemahan. ${ }^{11}$

R. Subekti yang menyatakan bahwa suatu perjanjian adalah suatu peristiwa di mana seseorang berjanji kepada orang lain atau di mana dua orang itu saling berjanji untuk melaksanakan sesuatu hal, dari peristiwa ini timbul suatu hubungan perikatan. ${ }^{12}$

Perjanjian adalah merupakan bagian dari perikatan, jadi perjanjian adalah merupakan sumber dari perikatan dan perikatan itu mempunyai cakupan yang lebih luas daripada

\footnotetext{
${ }^{10}$ R. Setiawan, Pokok-pokok Hukum Perikatan, Bina Cipta, Bandung, 1994, hal. 49.

${ }^{11}$ Purwahid Patrik, Dasar-dasar Hukum Perikatan (Perikatan yang lahir dariperjanjian dan dari UndangUndang), Mandar Maju, Bandung, 1994, hal. 46.

${ }^{12}$ R. Subekti, Hukum Perjanjian, Intermasa, Jakarta, 1987, hal. 1.
} 
perjanjian. Mengenai perikatan itu sendiri diatur dalam buku III KUH Perdata, sebagaimana diketahui bahwa suatu perikatan bersumber dari perjanjian dan undang-undang. Oleh karena itu bahwa perjanjian itu adalah sama artinya dengan kontrak.

R. Setiawan berpendapat bahwa definisi perjanjian berdasarkan Pasal 1313 KUHPerdata tersebut sebenarnya tidak lengkap, karena hanya mengatur perjanjian sepihak dan juga sangat luas karena istilah perbuatan yang dipakai akan mencakup juga perbuatan melawan hukum. ${ }^{13}$

Pendapat yang senada juga diungkapkan oleh para sarjana hukum perdata, pada umumnya menganggap definisi perjanjian menurut Pasal 1313 KUH Perdata itu tidak lengkap dan terlalu luas. R. Wirjono Prodjodikoro mengartikan perjanjian sebagai suatu hubungan hukum mengenai harta benda antara kedua belah pihak, dalam mana satu pihak berhak untuk menuntut pelaksanaan janji itu. ${ }^{14}$

Sedang menurut Abdul Kadir Muhammad merumuskan kembali definisi Pasal 1313 KUH Perdata sebagai berikut, bahwa yang disebut perjanjian adalah suatu persetujuan dengan mana dua orang atau lebih saling mengikatkan diri untuk melaksanakan sesuatu hal dalam lapangan harta kekayaan. ${ }^{15}$

Dari beberapa rumusan pengertian perjanjian seperti tersebut di atas, jika disimpulkan maka untuk perjanjian terdiri dari :

a. Ada pihak-pihak

Sedikitnya dua orang pihak ini disebut subyek perjanjian dapat manusia maupun badan hukum dan mempunyai wewenang melakukan perbuatan hukum seperti yang ditetapkan undang-undang.

b. Ada persetujuan antara pihak-pihak

Persetujuan antara pihak-pihak tersebut sifatnya tetap bukan merupakan suatu perundingan. Dalam perundingan umumnya dibicarakan mengenai syarat-syarat dan obyek perjanjian maka timbullah persetujuan.

c. Ada tujuan yang akan dicapai

Mengenai tujuan para pihak hendaknya tidak bertentangan dengan ketertiban umum, kesusilaan dan tidak dilarang oleh undang-undang.

d. Ada prestasi yang dilaksanakan.

Prestasi merupakan kewajiban yang harus dipenuhi oleh pihak sesuai dengan

\footnotetext{
${ }^{13}$ R. Setiawan, Op. Cit, hal. 49.

${ }^{14}$ R. Wiryono Projodikoro, Asas-asas Hukum Perjanjian, Sumur, Bandung, 1993, hal. 9.

${ }^{15}$ Abdul Kadir Muhammad, Hukum Perikatan, Citra Aditya Bakti, Bandung, 1992, hal. 78
} 
syarat-syarat perjanjian, misalnya pembelian berkewajiban untuk membeli harga barang dan penjual berkewajiban menyerahkan barang.

e. Ada bentuk tertentu lisan atau tulisan.

Perlunya bentuk tertentu karena ada ketentuan undang-undang yang menyebutkan bahwa dengan bentuk tertentu suatu perjanjian mempunyai kekuatan mengikat dan bukti yang kuat.

f. Ada syarat-syarat tertentu sebagai isi perjanjian.

Dari syarat-syarat tertentu dapat diketahui hak dan kewajiban para pihak. Syaratsyarat ini terdiri syarat pokok yang menimbulkan hak dan kewajiban pokok. ${ }^{16}$

\section{B. Asas-asas Penting dalam Perjanjian}

1) Asas kebebasan berkontrak

Maksudnya adalah setiap orang bebas mengadakan suatu perjanjian berupa apa saja, baik bentuknya, isinya dan pada siapa perjanjian itu ditujukan. Asas ini dapat didapat dilihat dari Pasal 1338 ayat (1) KUH Perdata yang berbunyi : "Semua persetujuan yang dibuat secara sah berlaku sebagai undang-undang bagi mereka yang membuatnya". Tujuan dari pasal di atas bahwa pada umumnya suatu perjanjian itu dapat dibuat secara bebas untuk membuat atau tidak membuat perjanjian, bebas untuk mengadakan perjanjian dengan siapapun, bebas untuk menentukan bentuknya maupun syarat-syarat, dan bebas untuk menentukan bentuknya, yaitu tertulis atau tidak tertulis dan seterusnya. ${ }^{17}$

Jadi dari pasal tersebut dapat diketahui bahwa masyarakat diperbolehkan membuat perjanjian yang berupa dan berisi apa saja (tentang apa saja) dan perjanjian itu mengikat mereka yang membuatnya seperti suatu undang-undang. Kebebasan berkontrak dari para pihak untuk membuat perjanjian itu meliputi :

a. Perjanjian yang telah diatur oleh undang-undang.

b. Perjanjian-perjanjian baru atau campuran yang belum diatur dalam Undangundang.

2) Asas konsensualisme

Adalah suatu perjanjian cukup ada kata sepakat dari mereka yang membuat perjanjian itu tanpa diikuti dengan perbuatan hukum lain kecuali perjanjian yang bersifat formal. $^{18}$

\footnotetext{
${ }^{16}$ R. Setiawan, Op. Cit. hal. 53

${ }^{17}$ A. Qiram Syamsudin Meliala, Pokok-pokok Hukum Perjanjian BesertaPerkembangannya, Liberty, Yogyakarta, 1985, hal. 19.

${ }^{18}$ Ibid, hal. 19.
} 
3) Asas iktikad baik

Orang yang akan membuat perjanjian harus dilakukan dengan itikad baik. Itikad baik dalam pengertian yang subyektif dapat diartikan sebagai kejujuran seseorang yaitu apa yang terletak pada seorang pada waktu diadakan perbuatan hukum. Sedangkan itikad baik dalam pengertian obyektif adalah bahwa pelaksanaan suatu perjanjian hukum harus didasarkan pada norma kepatuhan atau apa-apa yang dirasa sesuai dengan yang patut dalam masyarakat.

4) Asas Pacta Sun Servanda

Merupakan asas dalam perjanjian yang berhubungan dengan mengikatnya suatu perjanjian. Perjanjian yang dibuat secara sah oleh para pihak mengikat mereka yang membuatnya. Dan perjanjian tersebut berlaku seperti Undang-Undang. Dengan demikian para pihak tidak dapat mendapat kerugian karena perbuatan mereka dan juga tidak mendapat keuntungan darinya, kecuali kalau perjanjian tersebut dimaksudkan untuk pihak ketiga. Maksud dari asas ini dalam suatu perjanjian tidak lain untuk mendapatkan kepastian hukum bagi para pihak yang telah membuat perjanjian itu.

5) Asas berlakunya suatu perjanjian

Pada dasarnya semua perjanjian itu berlaku bagi mereka yang membuatnya tak ada pengaruhnya bagi pihak ketiga kecuali yang telah diatur dalam undang-undang, misalnya perjanjian untuk pihak ketiga. ${ }^{19}$

Asas berlakunya suatu perjanjian diatur dalam Pasal 1315 KUH Perdata yang berbunyi : "Pada umumnya tidak seorang pun dapat mengikatkan diri atas nama sendiri atau meminta ditetapkannya suatu perjanjian suatu janji dari pada untuk dirinya sendiri". ${ }^{20}$

\section{Syarat-syarat Perjanjian}

Agar perjanjian itu sah dan mempunyai kekuatan hukum, maka terlebih dahulu harus memenuhi syarat sahnya perjanjian yaitu perjanjian yang ditentukan undang-undang. Perlu diperhatikan bahwa perjanjian yang memenuhi undang-undang diakui oleh hukum, sebaliknya perjanjian yang tidak memenuhi syarat tak diakui oleh hukum walaupun diakui oleh pihak-pihak yang bersangkutan. Untuk itu apabila pihak-pihak mengakui dan mematuhi perjanjian yang mereka buat walaupun tidak memenuhi syarat perjanjian itu berlaku di antara mereka.

Apabila suatu ketika ada pihak yang tidak mengakuinya lagi, maka hakim akan membatalkan atau perjanjian itu batal. Berdasarkan Pasal 1320 KUH Perdata, untuk sahnya

\footnotetext{
${ }^{19}$ Ibid, hal. 20.

${ }^{20}$ Ibid, hal. 21
} 
suatu perjanjian para pihak harus memenuhi syarat-syarat tersebut di bawah ini :

1. Sepakat mereka yang mengikatkan diri.

2. Kecakapan para pihak dalam membuat suatu perjanjian.

3. Suatu hal tertentu.

4. Suatu sebab yang halal.

\section{1) Kesepakatan atau persetujuan kehendak pada pihak}

Kedua subjek yang mengadakan perjanjian itu harus bersepakat mengenai hal-hal yang pokok dari perjanjian yang diadakan itu. Apa yang dikehendaki oleh pihak yang satu, juga dikehendaki oleh pihak yang lain. Mereka menghendaki sesuatu yang sama secara timbal balik. Kedua belah pihak dalam suatu perjanjian, harus mempunyai kemauan yang bebas untuk mengikatkan diri dan kemauan itu harus dinyatakan. Pernyataan dapat dilakukan dengan tegas atau secara diam-diam.

Kemauan yang bebas sebagai syarat pertama untuk suatu perjanjian yang sah, dianggap tidak ada jika perjanjian itu telah menjadi karena :

a) Paksaan (dwang)

b) Kekhilafan (dwaling)

c) Penipuan (bedrog)

\section{2) Kecakapanpara pihak}

Orang yang membuat perjanjian harus cakap menurut hukum. Artinya yang membuat perjanjian dan akan terikat oleh perjanjian itu, harus mempunyai cukup kemampuan untuk menginsyafi benar-benar akan tanggung jawab yang dipikul atas perbuatannya. Sedangkan dari sudut ketertiban hukum, karena seorang yang membuat perjanjian itu berbarti mempertaruhkan kekayaannya, maka orang tersebut haruslah seorang yagn sungguhsungguh berhak berbuat dengan harta kekayaannya.

\section{3) Suatu hal tertentu}

Suatu perjanjian harus mengenai suatu hal tertentu, artinya apa yang diperjanjikan adalah mengenai suatu obyek tertentu yang telah disepakati.

\section{4) Suatu sebab atau causa yang halal}

Suatu perjanjian adalah sah bila sebab itu tidak dilarang oleh undang-undang, kesusilaan atau ketertiban umum. Karena perikatan menganut sistem terbuka, maka dalam pembuatan perjanjian dikenal asas kebebasan berkontrak, hal ini dapat dijumpai dalam Pasal 1338 KUHPerdata. Asas ini membebaskan orang untuk membuat atau tidak membuat perjanjian, dengan bentuk tertentu atau tidak dan bebas memilih undang-undang yang akan 
dipakainya untuk perjanjian itu. ${ }^{21}$

Secara umum tidak diatur mengenai formalitas suatu perjanjian dapat dilakukan secara lisan atau tertulis atau dengan suatu akta otentik. Namun demikian, KUHPerdata menentukan pengecualian terhadap ketentuan umum ini. Beberapa perjanjian khusus harus dibuat secara tertulis dengan suatu akta otentik yang dibuat dihadapan notaris. Dan ada pula beberapa perjanjian yang sudah dapat mengikat hanya dengan penyerahan dari pokok perjanjian.

Dalam praktek pada umumnya para pihak dari suatu perjanjian menginginkan dibuat setidak-tidaknya dalam bentuk tertulis baik yang dibuat sebagai perjanjian di bawah tangan atau dalam bentuk akta otentik (akta notariil) untuk memperkuat kedudukan mereka jika terjadi sengketa. Dalam peraturan perundang-undangan yang mengatur waralaba ditegaskan bahwa perjanjian waralaba harus dibuat dalam bentuk tertulis.

\section{Tinjauan Umum tentang Waralaba}

\section{Pengertian Waralaba}

Waralaba atau dalam istilah Bahasa Inggris disebut dengan Franchise merupakan suatu sistem yang berkembang dari lisensi dibidang hak milik intelektual di bidang penjualan barang-barang dan jasa. Apa yang terdapat dalam kontrak lisensi bisanya juga terdapat dalam suatu kontrak franchise, hanya suatu kontrak franchise biasanya lebih luas (comprehensif). Hal ini karena selain franchise harus memproduksi barang dan jasa yang sama dengan yang dibuat oleh franchisor atau perusahaan induknya, juga sering sekali pula harusdisajikan dan harus dipasarkan sesuai dengan cara yang dilakukan dan diminta oleh franchisor.

Franchise sebagai suatu cara melakukan kerjasama di bidangbisnis antara dua atau lebih perusahaan, satu pihak bertindak sebagai franchisor dan pihak lain sebagai franchisee, dimana di dalamnyadiatur, bahwa pihak franchisor sebagai pemilik suatu merek dan teknologi, memberikan haknya kepada franchise untuk melakukan kegiatan bisnis berdasarkan merek dan teknologi tersebut.

Ada beberapa pendapat lain yang dikemukakan oleh para ahli mengenai pengertian atau definisi dari franchise. Dalam hal ini akan dikemukakan beberapa pengertian mengenai franchise sebagai gambaran untuk mengetahui apa itu franchise.

Rooseno Harjowidigno mengemukakan definisi franchise sebagai berikut ${ }^{22}$

\footnotetext{
21 Purwahid Patrik, Asas-asas Itikad Baik dan Kepatutan Dalam Perjanjian, Semarang, Badan Penerbit UNDIP, 1986, hal. 3.

${ }^{22}$ Rooseno Harjowidigno, Aspek-aspek Hukum tentang Franchising, Seminar Ikadin, Surabaya, oktober, 1993, hal 17-18
} 
"Franchise adalah suatu sistem usaha yang sudah khas atau memiliki ciri mengenai bisnis dibidang perdagangan atau jasa, berupa jenis produk dan bentuk yang diusahakan, identitas perusahaan (logo, desain, merek bahkan termasuk pakaian dan penampilan karyawan perusahaan), rencana pemasaran dan bantuan operasional".

Sedangkan V. Winarto menyarankan suatu pengertian waralaba atau franchise adalah $:^{23}$

"Waralaba adalah hubungan kemitraan antara usahawan yang usahanya kuat dan sukses dengan usahawan yang relatif baru atau lemah dalam usaha tersebut dengan tujuan saling menguntungkan khususnya dalam bidang usaha menyediakan produk dan jasa langsung kepada konsumen".

Sebagaimana telah disebutkan di atas franchise sebenarnya telah mendapat padanan kata dalam bahasa Indonesia, namun bagi yang telah terbiasa menggunakan kata franchise akan terasa kurang mantap bila diganti dengan kata-kata lokal yang belum sering dipakai.

Pilihan kata untuk padananfranchise ini adalah "Waralaba" yang berarti keuntungan istimewa. Upaya menterjemahkan istilah franchise ke dalam bahasa Indonesia oleh V. Winarto ini patut dihargai, karena akan memudahkan untuk lebih mengenal franchise.

Di dalam kamus ekonomi bisnis perbankan mengartikan bahwa franchise adalah "suatu hak tunggal yang diberikan kepadaperorangan atau suatu organisasi, oleh suatu pihak lain, baik perorangan atau organisasi (perusahaan, pemerintah dan sebagainya) untuk menjalankan suatu wewenang khususnya menyangkut perbuatan dan atau penjualan di wilayah tertentu. ${ }^{24}$

Menurut Martin Mendelsohn format bisnis franchise ini adalah $:^{25}$

"Pemberian sebuah lisensi (franchisor) kepada pihak lain (franchisee), lisensi tersebut memberikan hak kepada franchisee untuk berusaha dengan menggunakan merekdagang franchisor, dan untuk menggunakan keseluruhan paket yang terdiri dari seluruh elemen yang diperlukan untuk membuat seseorang yang sebelumnya belum terlatih dalam menjalankan bisnis dan untuk menjalankan dengan bantuan terus menerus atas dasar-dasar yang telah ditentukan sebelumnya".

Dari sudut pandang ekonomi franchise adalah hak yang diberikan secara

\footnotetext{
${ }^{23}$ Ibid, hal. 19.

${ }^{24}$ T. Guritno, Kamus Ekonomi Bisnis Perbankan, Gajah Mada University Press, Cetakan I, 1992.

${ }^{25}$ Martin Mendelsohn, Franchising : Petunjuk Praktis bagi Franchisor danFranchisee, PT. Pustaka Binaman Perssindo, 1997, hal. 4.
} 
khusus kepada seseorang atau kelompok, untuk memproduksi atau merakit, menjual, memasarkan suatu produk atau jasa. Sedangkan dari sudut pandang hukum franchise adalah perjanjian legal antara dua pihak dalam bekerjasama memproduksi, merakit, menjual, memasarkan suatu produk jasa.

Tri Raharjo dalam salamfrinchise.com, menyebutkan bahwa franchise adalah sistim pemasaran atau distribusi barang dan jasa, dimana sebuah perusahaan induk (franchisor) memberikan kepada individu atau perusahaan lain (franchisee) yang berskala kecil dan menengah, hak istimewa untuk melakukan suatu sistem usaha tertentu, dengan cara tertentu, waktu tertentu, dan di suatu tempat tertentu. Lebih lanjut disebutkan bahwa franchise adalah suatu hubungan berdasarkan kontrak antara franchisor dan franchisee. Franchisor berkewajiban untuk menyediakan perhatian terus-meneruspada bisnis dari franchisee melalui penyediaan pengetahuan dan pelatihan. Franchisee beroperasi dengan menggunakan nama dagang, format, atau prosedur yang dipunyai serta dikendalikan oleh franchisor. Franchisee melakukan investasi dalam bisnis yang dimilikinya. ${ }^{26}$

Hubungan kerjasama franchise terwujud bila terdapat sebagai berikut:

1. Ada paket usaha yang ditawarkan oleh franchisor;

2. Franchisee adalah pemilik unit usaha.

3. Ada kerjasama antara franchisee dan franchisor dalam pengelolaan unit usaha.

4. Ada kontrak tertulis yang mengatur kerjasama antara franchisordan franchisee

\section{Perjanjian Waralaba Sebagai Bentuk Perjanjian Berdasarkan Pasal 1320 Kitab Undang-Undang Hukum Perdata}

Waralaba merupakan suatu perikatan / perjanjian antara dua pihak. Sebagai perjanjian dapat dipastikan terikat pada ketentuan dalam Hukum Perdata(KUH Perdata) tentang perjanjian (pasal 1313), sahnya perjanjian (pasal 1320)dan kebebasan berkontrak (pasal 1338).

Selanjutnya untuk sahnya suatu perjanjian menurut pasal 1320 Kitab UndangUndang Hukum Perdata diperlukan empat syarat yaitu: ${ }^{27}$

a. Kesepakatan (toesteming / izin) kedua belah pihak

Kesepakatan ini diatur dalam pasal 1320 ayat (1) KUH Perdata, yangdimaksud kesepakatan adalah persesuaian pernyataan kehendak antarasatu orang atau lebih

\footnotetext{
26 Tri Raharjo, salamfrinchise.com

${ }^{27}$ Salim.HS, Hukum Kontrak Teori Dan Teknik penyusunan kontrak, Sinar Grafika, Jakarta, 2003, hal. 33
} 
dengan pihak lainnya. Yang sesuai adalahpernyataannya, karena kehendak itu tidak dapat dilihat / diketahui oranglain.

b. Kecakapan Bertindak

Kecakapan bertindak adalah kecakapan atau kemampuan untukmelakukan perbuatan hukum. Perbuatan hukum adalah perbuatan yangakan menimbulkan akibat hukum. Orang-orang yang akan mengadakanperjanjian haruslah orang-orang yang cakap dan mempunyai wewenanguntuk melakukan perbuatan hukum, sebagaimana yang ditentukan oleh undang-undang Bekwaam (cakap) merupakan syarat umum untuk dapat melakukanperbuatan hukum secara sah, yaitu harus sudah dewasa, sehat akal pikiran,dan tidak dilarang oleh sesuatu peraturan perundang-undangan untukmelakukan suatu perbuatan tertentu

c. Mengenai suatu hal tertentu

Suatu hal tertentu adalah barang yang menjadi obyek dalam kontrak.Menurut pasal 1333 Kitab Undang-Undang Hukum Perdata, barang yangmenjadi obyek suatu kontrak harus tertentu, setidak-tidaknya harusditentukan jenisnya. Demikian juga jumlahnya perlu ditentukan asal dapatditentukan dan diperhitungkan.

d. Suatu sebab yang halal (Geoorloofde oorzaak)

Halal merupakan syarat keempat sebagai sahnya suatu kontrak. Pasal 1335 Kitab Undang-Undang Hukum Perdata menegaskan "jika kontrak tanpa sebab, atau kontrak karena sebab palsu atau terlarang maka tidak mempunyai kekuatan"

Dua syarat yang pertama, dinamakan syarat-syarat subyektif, karenamengenai orangorangnya atau subyeknya yang mengadakan perjanjian,sedangkan dua syarat yang terakhir dinamakan syarat-syarat obyektifkarena mengenai perjanjiannya sendiri atau obyek dari perbuatan hukumyang dilakukan itu. ${ }^{28}$

Apabila syarat pertama dan kedua tidak terpenuhi maka perjanjian itu dapatdibatalkan. Artinya, bahwa salah satu pihak dapat mengajukan kepada pengadilanutuk membatalkan perjanjian yang disepakatinya. Tetapi apabila para pihak tidak adayang keberatan maka perjanjian itu tetap dianggap sah. Syarat ketiga dan keempattidak terpenuhi maka perjanjian itu batal demi hukum. Artinya bahwa dari semulaperjanjian itu dianggap tidak ada. ${ }^{29}$

Ada beberapa syarat untuk kontrak yang berlaku umum tetapi di atur di luarpasal 1320 KUH Perdata, yaitu sebagai berikut :

\footnotetext{
${ }^{28}$ Subekti, Hukum Perjanjian, PT Intermasa, Jakarta, 2002, hal. 17

${ }^{29}$ Salim HS, op. cit, hal. 34 - 35
} 
a. Kontrak harus dilakukan dengan itikad baik

b. Kontrak tidak boleh bertentangan dengan kebiasaan yang berlaku

c. Kontrak harus dilakukan berdasarkan asas kepatutan

d. Kontrak tidak boleh melanggar kepentingan umum

Apabila kontrak dilakukan dengan melanggar salah satu dari 4 (empat)prinsip tersebut, maka konsekuensi yuridisnya adalah bahwa kontrak yang demikiantidak sah dan batal demi hukum (null and void).

Adapun pasal 1338 ayat (1) Kitab Undang-Undang Hukum Perdata berbunyi“"semua perjanjian yang dibuat secara sah berlaku sebagai undang-undang bagimereka yang membuatnya".Walaupun dalam suatu perjanjian mengatur sistem terbuka / bebas(open sistem) namun tetap dibatasi oleh beberapa hal, misalnya :

- Dibatasi undang-undang, adalah dilarang membuat perjanjian tanpa harga, perjanjian penetapan di bawah harga dan lain-lain karena menyangkut persaingan ekonomi yang tidak sehat.

- Dibatasi untuk ketertiban umum, misalnya perjanjian pemboikotan terhadap produk, perjanjian tertutup,

- Bertentangan dengan kesusilaan, misalnya perjanjian tentang perdagangan wanita, perjanjian tentang bentuk pertaruhan dan lain-lain.

Sebagai suatu transaksi yang melahirkan perjanjian, waralaba selalumelibatkan dua pihak. Kedua belah pihak tersebut memiliki kepentingan yang berdirisendiri dan kadangkala bertolak belakang, meskipun secara konseptual dapatdikatakan bahwa kedua belah pihak tersebut, yaitu pemberi lisensi dan pemberiwaralaba maupun penerima lisensi dan penerima waralaba, pasti akan mencarikeuntungan yang sebesar-besarnya. Maksud untuk mencari keuntungan sebesar-besarnyaini jugalah yang pada pokoknya menjadi sumber perbedaan kepentingan dan perselisihan yang dapat terjadi di antara kedua belah pihak tersebut. Keuntungan yangbesar ini hanya dapat dicapai oleh kedua belah pihak jika antar kedua belah pihak dapat menjalin sinergisme yang saling menguntungkan. Perjanjian waralaba ini merupakan bentuk perlindungan hukum yang diberikan kepada para pihak, dan perjanjian tersebut merupakan perjanjian baku timbal balik karena masing-masing pihak mempunyai hak dan kewajiban yang seimbang mengedepankan prinsip win-win solution yang saling menguntungkan.

Pendirian waralaba dapat terwujud karena adanya kesepakatan kedua belahpihak antara franchisor dengan franchisee dan sebagai perjanjian tunduk padaketentuan dalam 
Hukum Perdata tentang Perjanjian yang diatur dalam pasal 1313KUH Perdata tentang Perjanjian yang mengandung konsekwensi hukum bahwa dalam suatu perjanjian akan selalu ada dua pihak dimana satu pihak adalah yangwajib berprestasi (debitur) dan pihak lainnya adalah pihak yang berhak atas prestasi(kreditur). Jadi disini baik pemberi waralaba maupun penerima waralaba keduanyaberkewajiban untuk memenuhi prestasi tertentu.

Para pihak yang membuat kontrak telah sepakat dan berkesesuaian dalam kemauan dan saling menyetujui kehendak masing-masing, yang dilahirkan oleh para pihak tanpa ada paksaan, kekeliruan, dan penipuan. Pelaksanaan perjanjian yang dibuat para pihak adalah sah karena telah memenuhi syarat-syarat yang ditentukan dalam pasal 1320 KUH Perdata.

Kesepakatan dari para pihak adalah asas esensial dari Hukum Perjanjian yang mengandung arti "kemauan" (will) para pihak untuk saling berprestasi dan adakemauan untuk saling mengikatkan diri. Kemauan ini menimbulkan kepercayaan(vertrouwen) bahwa perjanjian itu dipenuhi. Asas konsensualisme berhubungan erat dengan asas kebebasan berkontrak dan asas kekuatan mengikat yang terdapat dalam pasal 1338 ayat (1) KUH Perdata yang menyebutkan "semua persetujuan yang dibuat secara sah berlaku sebagai undang-undang bagi mereka yang membuatnya"

Asas kebebasan berkontrak tidak mempunyai arti tidak terbatas, akan tetapiterbatas oleh tanggung jawab para pihak dengan meletakkan kedudukan yangseimbang di antara para pihak dengan prinsip saling memberikan keuntungan.Maksud dari pasal tersebut adalah memberikan kebebasan kepada para pihak untuk :

1. Membuat atau tidak membuat perjanjian;

2. Mengadakan perjanjian dengan siapapun;

3. Menentukan isi perjanjian, pelaksanaan, dan persyaratannya;

4. Menentukan bentuk perjanjian, yaitu tertulis atau lisan.

Perjanjian waralaba dapat dikatakan suatu perjanjian yang tidak bertentangandengan undang-undang, agama, ketertiban umum, dan kesusilaan. Artinyaperjanjian waralaba tersebut sah dan oleh karena itu perjanjian itu menjadi undang-undang bagi mereka yang membuatnya, dan mengikat kedua belah pihak.

\section{Praktek Pelaksanaan Perjanjian Waralaba}

Waralaba yang dalam bahasa Inggris disebut dengan Franchise telah menjadi istilah yang cukup dikenal dewasaini ditengah-tengah masyarakat, khususnya pelaku usaha.Mengingat waralaba merupakan pola pengembangan usahayang cukup menarik dan banyak dilakukan. Berbagaibentuk usaha yang telah mempunyai brand image atauterkenal di masyarakat kemudian diwaralabakan. 
Gerai-gerai waralaba sangat mudah ditemukan terutama di kawasan perkotaan sampai pedesaan, dewasa ini begitu mudah kita menemukan jaringan waralaba minimarket maupun waralaba makanan cepat saji, baikwaralaba asing maupun lokal, semuanya berkompentisi merebut pangsa pasar masing-masing..hampir semua segmen bisnis telah diwaralabakan, seperti salonkecantikan, apotik, mini markert, usaha makanan, layanan perkantoran, dan masih banyak lagi jenis usaha waralaba tersebut.

Waralaba telah menjadi strategi pemasaran yangbertujuan untuk memperluas jangkauan usaha untukmeningkatkan pangsa pasar atau penjualannya.Pengembangan usaha semakin cepat dengan dana yangrelatif terbatas, karena dengan melibatkan investor lainuntuk turut serta menggunakan pengalaman, hak kekayaan intelektual, sistem atau cara kerja serta ketrampilan yang dimilikinya.

Seringkali antara waralaba atau franchise disamakan dengan lisensi, padahal keduanya berbeda. Pada lisensihanya memberikan ijin untuk menggunakan hak kekayaan intelektual tertentu saja, sedangkan pada waralaba lebih luas daripada lisensi. Hal ini disebaban pada waralaba didalamnya antara lain ada lisensi penggunaan hak kekayaan intelektual yang disertai dengan suatu sistem kerja,ketrampilan, pengalaman dan berbagai sistem pelayanan yang dimilikinya.

Waralaba memungkinkan perusahaan untuk melakukan penetrasi pasar tanpa harus keluar biayasendiri. Perusahaan sebagai pemberi waralaba atau dalamBahasa Inggiris diistilahkan dengan franchisor dapat memegang kendali atas penerima waralaba (franchisee)dengan memberikan dukungan perihal strategi penjualan-pelayanan,reputasi, merek, dan standard kualitas serta dukungan lainnya. Dukungan ini tentunya diimbangi dengan imbalan fee yang fixed atau variabel secara periodik. Jadi intinya waralaba memungkinkan perusahaan untuk memperluas jaringan bisnis dan sekaligus memperkecil risiko karena ada proses berbagi risikodengan franchisee. ${ }^{30}$

Berdasarkan Pasal 1 Peraturan Pemerintah No. 42Tahun 2007 tentang Waralaba, pengertian waralaba adalah hak khusus yang dimiliki oleh orang perseorangan atau badan usaha terhadap sistem bisnis dengan ciri khasusaha dalam rangka memasarkan barang dan/atau jasayang telah terbukti berhasil dan dapat dimanfaatkan dan/atau digunakan oleh pihak lain berdasarkan perjanjianwaralaba.

\footnotetext{
${ }^{30}$ Roy Sembel dan Tedy Ferdiansyah, Tujuh Jurus Pendanaan di Tahun Kuda Air, Jakarta : USAHAWAN No. 03 Th. XXXI, (2002).
} 
Dengan cara waralaba perusahaan melakukan pengembangan pasar tanpa harus mengeluarkan investasi baru, bahkan dapat memberikan kesempatan kepada pihak lain untuk turut serta menjalankan usahanya. Perusahaan sebagai pemberi waralaba akan mengendalikan penerima waralaba dalam menjalankan usahanya, yaitu dengan memberikan dukungan sepenuhnya sesuai dengan yang diperjanjikan.

Pasal 3 Peraturan Pemerintah No. 42 Tahun 2007 fktentang Waralaba menjelaskan bahwa suatu waralaba memiliki kriteria-kriteria yang khusus yaitu:

a. Memiliki ciri khas usaha, yaitu suatu usaha yangmemiliki keunggulan atau perbedaan yang tidak mudah ditiru dibandingkan dengan usaha lain sejenis, danmembuat konsumen selalu mencari ciri khas dimaksud.Misalnya, sistem manajemen, cara penjualan dan pelayanan, atau penataan atau cara distribusi yang merupakan karakteristik khusus dari Pemberi Waralaba.

b. Terbukti sudah memberikan keuntungan, hal ini menunjuk pada pengalaman Pemberi Waralaba yang telah dimiliki kurang lebih 5 (lima) tahun dan telah mempunyai kiat-kiat bisnis untuk mengatasi masalah-masalah dalam perjalanan usahanya, dan ini terbukti dengan masih bertahan dan berkembangnya usaha tersebut dengan menguntungkan.

c. Memiliki standar atas pelayanan dan barang dan/atau jasa yang ditawarkan yang dibuat secara tertulis, adalah standar secara tertulis supaya Penerima Waralaba dapat melaksanakan usaha dalam kerangka kerja yang jelas dan sama (Standard Operational Procedure).

d. Mudah diajarkan dan diaplikasikan, sehingga Penerima Waralaba yang belum memiliki pengalaman atau pengetahuan mengenai usaha sejenis dapat melaksanakannya dengan baik sesuai dengan bimbingan operasional dan manajemen yang berkesinambungan yang diberikan oleh PemberiWaralaba.

e. Adanya dukungan yang berkesinambungan dari Pemberi Waralaba kepada Penerima Waralaba secara terus menerus seperti bimbingan operasional, pelatihan, danpromosi.

f. Hak Kekayaan Intelektual yang telah terdaftar, adalah Hak Kekayaan Intelektual yang terkait dengan usaha seperti merek, hak cipta, paten, dan rahasia dagang, sudah didaftarkan dan mempunyai sertipikat atau sedang dalam proses pendaftaran di instansi yang berwenang.

Pengembangan usaha melalui waralaba padadasarnya mengembangkan usaha secara cepat memakaimodal pihak lain, tentu saja risikonya juga ditanggung olehpenerima 
waralaba. Penerima waralaba akanmendapatkan pelatihan, sistem, hak kekayaan intelektual,bahkan peralatan maupun bahan baku, tanpa harus memiliki pengalaman usaha lebih dahulu. Adapunpemberi waralaba mempunyai hak untuk mendapatkan franchise fee atas penggunaan merek dan sistem, yang diterimakan pada awal perjanjian untuk suatu jangka waktutertentu biasanya sekurang-kurangnya lima tahun. Selainitu juga mendapatkan royalty dari penerima waralaba, yangberupa persentase dari nilai penjualan setiap bulannya.

Pada dasarnya waralaba terbentuk ketika pemberiwaralaba menjalin hubungan hukum untuk melakukankontrak kerjasama secara terpadu terhadap merek, desaintata letak dan lain sebagainya yang berkenaan dengan hak kekayaan intelektual serta metode bisnis secara kontinyu dalam suatu periode tertentu dengan penerima waralaba.

Berkembang dari bentuk dasar itu, dikenal empat jenisfranchise atau waralaba tambahan.

1. Master Franchise. Dalam kontrak ini, franchisee juga berhak menjual hak franchise yang dimilikinya pada peminat lain yang berada dalam wilayah tertentu;

2. Area Development Program. Di sini franchisee memiliki hak mengembangkan bisnis franchise yang bersangkutan dalam suatu wilayah tertentu, tanpa memiliki hak menjual ulang hak yang dimilikinya. Jadi bedanya dengan master franchise hanya pada ada tidaknya hak untuk menjual ulang franchise yang dibelinya.

3. Joint Venture Franchise Program. Kontrak ini terjadi jika francisor ikut menginvestasikan dana selain memberikan dukungan manajemen dan teknis. Franchisee tetap bertugas mengembangkan dan mengoperasikan tempat usaha yang bersangkutan. Biaya-biaya yang timbul dan keuntungan yang diperoleh akan dibagi oleh franchisor dan franchisee sesuai dengan perjanjian.

4. Mixed Franchise. Tipe ini terjadi jika franchisor menawarkan paket franchise yang memungkinkan franchisee yang modalnya terbatas untuk mengelola sebagian fungsi usaha saja. Misalnya produksi dilakukanh franchisor dan franchisee hanya mengelola proses penjualannya saja. Selain paket seperti itu, franchisor tersebut biasanya juga menawarkan paket utuh kepada franchisee yangmemiliki modal cukup. ${ }^{31}$

Perjanjian Waralaba mengatur hubungan hokum antara pemberi waralaba dengan penerima waralaba untuk menjalankan kegiatan waralaba. Pada dasarnya

\footnotetext{
${ }^{31}$ Handowo Dipo, Sukses Usaha Memperoleh Dana, dengan Konsentrasi Modal Ventura, Jakarta, Grafiti Press, 1993, hal. 39
} 
waralabamerupakan salah satu bentuk pemberian lisensi, hanyasaja agak berbeda dengan pengertian lisensi padaumumnya, waralaba menekankan pada kewajiban untukmenggunakan sistem, metode, tata cara, prosedur, metodepemasaran dan penjualan maupun hal-hal lain yang ditentukan oleh pemberi waralaba secara eksklusif, serta tidak boleh dilanggar maupun diabaikan oleh penerima lisensi. Hal ini mengakibatkan bahwa waralaba cenderung bersifat eksklusif. Seorang atau suatu pihak yang menerima waralaba tidaklah dimungkinkan untuk melakukan kegiatan lain yang sejenis atau yang berada dalam suatu lingkungan yang mungkin menimbulkan persaingan dengan kegiatan usaha waralaba yang diperoleh olehnya dari pemberi waralaba. ${ }^{32}$

Berdasarkan pengertian yang dikemukakan oleh Gunawan Widjaya tersebut di atas, maka dalam pembuatan perjanjian atau kontrak harus dibuat secara terang dansejelasjelasnya, hal ini disebabkan saling member kepercayaan dan mempunyai harapan keuntungan bagi kedua pihak akan diperoleh secara cepat. Karena itu kontrak waralaba merupakan suatu dokumen yang didalamnya berisi suatu transaksi yang dijabarkan secaraterperinci.

Berdasarkan Pasal 4 ayat (1) dan (2) PeraturanPemerintah No. 42 Tahun 2007 tentang Waralaba, menyebutkan bahwa Waralaba diselenggarakan berdasarkan perjanjian tertulis antara Pemberi Waralaba dengan Penerima Waralaba dengan memperhatikan hokum Indonesia.Dalam hal perjanjian sebagaimana dimaksud pada ayat (1)ditulis dalam bahasa asing, perjanjian tersebut harus diterjemahkan ke dalam bahasa Indonesia. ${ }^{33}$

Prospektus penawaran waralaba tersebut di atas memuat palingsedikit sebagaimana tercantum dalam Lampiran I Peraturan MenteriPerdagangan Republik Indonesia Nomor: 31/M-DAG/PER/8/2008 tentang Penyelenggaraan Waralaba, yaitu:

1. Data identitas Pemberi Waralaba, yaitu fotokopi Kartu Tanda Penduduk atau paspor pemilik usaha apabila perseorangan, dan fotokopi Kartu Tanda Penduduk atau paspor para Pemegang Saham, Komisaris dan Direksi apabila berupa badan usaha.

2. Legalitas usaha Waralaba, yaitu izin usaha teknis seperti Surat Izin Usaha Perdagangan (SIUP), Izin Tetap Usaha Pariwisata, Surat Izin Pendirian Satuan Pendidikan atau izin usaha yang berlaku di Negara Pemberi Waralaba.

\footnotetext{
${ }^{32}$ Gunawan Widjaya, Lisensi Atau Waralaba, Suatu Panduan Praktis, Jakarta, Raja Grafindo Persada, 2002, hal. 20

${ }^{33}$ Ibid, hal 21
} 
3. Sejarah kegiatan usahanya, yaitu uraian yang mencakup antara lain mengenai pendirian usaha, kegiatan usaha, dan pengembangan usaha.

4. Struktur organisasi Pemberi Waralaba, yaitu struktur organisasi usaha Pemberi Waralaba mulai dari Komisaris, Pemegang Saham dan Direksi sampai ke tingkat operasional termasuk dengan Pewaralaba/Franchiseenya.

5. Laporan keuangan 2 (dua) tahun terakhir, yaitu laporan keuangan atau neraca keuangan Perusahaan Pemberi Waralaba 2 (dua) tahun berturut-turut dihitung mundur dari waktu permohonan Prospektus Penawaran Waralaba.

6. Jumlah tempat usaha, yaitu outlet/gerai usaha waralaba sesuai dengan Kabupaten/Kota domisili untuk Pemberi Waralaba Dalam Negeri dan sesuai dengan negara domisili outlet/gerai untuk Pemberi Waralaba Luar Negeri.

7. Daftar Penerima waralaba, yaitu daftar nama dan alamat perusahaan dan/atau perseorangan sebagai Penerima waralaba dan perusahaan yang membuat prospektus penawaran waralaba baik yang berdomisili di Indonesia maupun di Luar Negeri.

8. Hak dan kewajiban Pemberi Waralaba dan Penerima Waralaba, yaitu hak yang dimiliki baik oleh Pemberi Waralaba maupun PenerimaWaralaba, seperti;

a. Pemberi Waralaba berhak menerima fee atau royalty dari Penerima Waralaba, dan selanjutnya Pemberi Waralaba berkewajiban memberikan pembinaan secara berkesinambungankepada Penerima Waralaba.

b. Penerima Waralaba berhak menggunakan Hak Kekayaan Intelektual atau ciri khas usaha yang dimiliki Pemberi Waralaba, dan selanjutnya Penerima Waralaba berkewajiban menjaga Kode Etik/kerahasiaan HKI atau ciri khas usaha yang diberikan PemberiWaralaba.

Kewajiban yang melekat terhadap pemberi waralaba untuk prospektus penawaran waralaba kepada penerima waralaba sebelum penandatanganan perjanjian waralabamerupakan hal yang baru dalam pengaturan waralaba diIndonesia, hal ini menurut penulis sangat signifikan dalamsuatu kegiatan pra kontrak, mengingat melalui prospectus tersebut penerima waralaba dapat mempelajari sertamempertimbangankan berbagai aspek yang terkait dengan waralaba yang ditawarkan, dalam hal ini termasuk aspek hukum.

\section{Perlindungan Hukum Para Pihak dalam Praktek Bisnis Waralaba}

Pemerintah sebagai pemegang otoritas mempunyai kekuasaan untukmenerapkan peraturan-peraturan yang menyangkut hubungan bisnis bagi para pihaksekaligus melakukan 
pengawasan terhadap pelaksanaan undang-undang, yaitu agarsupaya undang-undang yang telah dibuat Pemerintah tersebut dapat dilaksanakandengan baik tanpa adanya suatu pelanggaran atau penyelewengan. PerhatianPemerintah yang begitu besar ini bertujuan memberikan perlindungan hukum sertakepastian hukum agar masing-masing pihak merasa aman dan nyaman dalam menjalankan bisnis khususnya yang terlibat dalam bisnis waralaba ini.

Hukum bisnis waralaba idealnya untuk melindungi kepentingan para pihaknamun kenyataan di lapangan belum tentu sesuai seperti yang diharapkan. Seperti yang dikemukakan oleh Roscoe Pound yang membagi 3 (tiga) golongan yang harusdilindungi oleh hukum, yaitu, kepentingan umum, kepentingan sosial dan kepentingan perseorangan. ${ }^{34}$ Akan tetapi posisi pemberi waralaba yang secara ekonomi lebih kuat akan memberikan pengaruhnya pula bagi beroperasinya hukum di masyarakat.

Hukum mempunyai kedudukan yang kuat, karena konsepsi tersebutmemberikan kesempatan yang luas kepada negara atau Pemerintah untuk mengambil tindakan-tindakan yang diperlukan untuk membawa masyarakat kepada tujuan yang di kehendaki dan menuangkannya melaui peraturan yang dibuatnya. Dengandemikian hukum bekerja dengan cara memberikan petunjuk tingkah laku kepadamanusia dalam memenuhi kebutuhan.

Satjipto Rahardjo mengatakan bahwa ketaatan perbuatan terhadap ketentuanketentuan organisasi dipengaruhi oleh kepribadian, asal-usul sosial, kepentinganekonominya, maupun kepentingan politik serta pandangan hidupnya maka semakinbesar pula kepentingannya dalam hukum. ${ }^{35} \mathrm{Di}$ sisi lain diungkapkan juga bahwa masyarakat senantiasa mengalami perubahan demikian pula dengan hukumnya,bahwa hukum itu berkembang dengan mengikuti tahap-tahap perkembanganmasyarakat. Sedangkan kunci utama dalam pembuatan hukum yang mengarah kepadaperubahan sosial terletak pada pelaksanaan ataupun implementasi-implementasi hukum tersebut. ${ }^{36}$

Meskipun demikian hukum juga memiliki keterbatasan dalam melakukantugasnya dalam masyarakat, baik yang timbul dari hukum itu sendiri maupun yang timbul dari luar hukum. Sebagai contoh hukum mempunyai sifat yang kaku karena tidak dapat mengetahui situasi yang akan terjadi pada saat hukum akan diterapkan.

\footnotetext{
${ }^{34}$ Satjipto Rahardjo, Ilmu Hukum, Alumni Bandung 1982, hal, 266

${ }^{35}$ Satjipto Rahardjo, Hukum Dan Masyarakat, Angkasa, Bandung, 1980, hal. 72

${ }^{36}$ Satjipto Rahardjo (1982), op. cit, hal. 333
} 
Faktor di luar hukum ini adalah faktor sosial, budaya, ekonomi dan lingkungan dalam masyarakat. ${ }^{37}$ Oleh sebab itu dalam membuat suatu peraturan harus mempertimbangkan factor-faktor tersebut agar hukum benar-benar berfungsi sebagaimana mestinya.Hukum merupakan pencerminan kehendak manusia tentang bagaimana seharusnyamasyarakat dibina dan kemana harus diarahkan. Supaya hukum dapatberfungsi dengan baik maka diperlukan keserasian dalam hubungan antara empat faktor, yaitu : ${ }^{38}$

1. Hukum dan peraturannya sendiri.

2. Mentalitas petugas yang menegakkan hukum.

3. Fasilitas yang diharapkan untuk mendukung pelaksanaan hukum.

4. Kesadaran hukum, kepatuhan hukum dan perilaku warga masyarakat.

Sebagaimana yang dikatakan kembali oleh Soerjono Soekanto, bahwa suatusikap tindak atau perilaku hukum dianggap efektif apabila sikap tindak atau perilakupihak lain menuju pada tujuan yang dikehendaki artinya apabila pihak lain tersebutmematuhi hukum dan hukum akan semakin efektif apabila peranan yang dijalankanoleh subjek hukum semakin mendekati apa yang telah ditentukan oleh hukum. ${ }^{39}$

Dapat dikatakan pula ada interaksi diantara keputusan-keputusan hukumdan masyarakat tempat keputusan itu dijalankan nantinya oleh karena adanya kebutuhan untuk penyesuaian sosial yang demikian itulah maka sesuatu norma hukum bisa saja berubah-ubah isinya tanpa terjadinya perubahan peraturan itu sendirisecara formal. ${ }^{40}$

Waralaba menurut pasal 1 Peraturan Pemerintah RI No 16 tahun 1997 adalah"perikatan dimana salah satu pihak diberikan hak untuk memanfaatkan dan ataumenggunakan hak atas kekayaan intelektual atau penemuan atau ciri khas usaha yangdimiliki pihak lain dengan suatu imbalan berdasarkan persyaratan dan atau penjualanbarang dan atau jasa”.

Sedangkan berdasarkan Peraturan Pemerintah RI No. 42 Tahun 2007 pasal 1ayat (1) menyebutkan pengertian waralaba adalah: "hak khusus yang dimiliki olehorang perseorangan atau badan usaha terhadap sistem bisnis dengan ciri khas usaha dalam rangka

\footnotetext{
${ }^{37}$ Robert B. Seidmend, Law and Development:A General Model, dalam Law and Society Review, tahun VI ( 1972 ), hal. 311 - 319

38 Soerjono Soekanto, Beberapa Permasalahan Dalam Kerangka Pembangunan di Indonesia, Universitas Indonesia, Jakarta, 1984, hal. 36

${ }^{39}$ Soerjono Soekanto, dan Sri Mamudji, Penelitian Hukum Normatif Suatu Tinjauan Singkat, Rajawali Press, Jakarta, 1998, hal. 52

${ }^{40}$ Satjipto Rahardjo, Hukum dan Perubahan Sosial, Alumni, Bandung, 1979, hal. 61.
} 
memasarkan barang dan / atau jasa yang telah terbukti berhasil dandapat dimanfaatkan dan / atau digunakan oleh pihak lain berdasarkan perjanjianwaralaba"

Dalam franchise ada dua pihak yang terlibat yaitu franchisor atau pemberiwaralaba dan franchisee atau penerima waralaba di mana masing-masing pihakterikat dalam suatu perjanjian yaitu perjanjian waralaba. Peraturan Pemerintah RI No.42 Tahun 2007 dalam pasal 1 ayat (2) yang dimaksud franchisor atau pemberi waralaba adalah orang perseorangan atau badan usaha yang memberikan hak untukmemanfaatkan dan / atau menggunakan waralaba yang dimilikinya kepada penerima waralaba dan dalam pasal 1 ayat (3) yang dimaksud franchisee atau penerimawaralaba adalah orang perseorangan atau badan usaha yang diberikan hak olehpemberi waralaba untuk memanfaatkan dan / atau menggunakan waralaba yangdimiliki pemberi waralaba.

Sementara itu dalam pasal 3 ada enam syarat yang harus dimiliki suatu usahaapabila ingin diwaralabakan yaitu :

1. Memiliki ciri khas usaha

Suatu usaha yang memiliki keunggulan atau perbedaan yang tidak mudahditiru dibandingkan dengan usaha lain sejenis, dan membuat konsumen selalu mencari ciri khas dimaksud. Misalnya sistem manajemen, cara penjualan dan pelayanan, atau penataan atau cara distribusi yang merupakan karakteristik khusus dari pemberi waralaba.

2. Terbukti sudah memberikan keuntungan

Menunjuk pada pengalaman pemberi waralaba yang telah dimiliki yangkurang lebih 5 tahun dan telah mempunyai kiat-kiat bisnis untuk mengatasi masalahmasalah dalam perjalanan usahanya, dan ini terbukti engan masih bertahan dan berkembangnya usaha tersebut denganmenguntungkan.

3. Memiliki standar atas pelayanan dan barang dan / atau jasa yang ditawarkan yang dibuat secara tertulis

Usaha tersebut sangat mebutuhkan standar secara tertulis supaya penerimawaralaba dapat melaksanakan usaha dalam kerangka kerja yang jelas dansama / Standard Operasional Prosedur.

4. Mudah diajarkan dan diaplikasikan

Mudah dilaksanakan sehingga penerima waralaba yang belum memiliki pengalaman atau pengetahuan mengenai usaha sejenis dapatmelaksanakannya dengan baik sesuai dengan bimbingan operasional danmanajemen yang berkesinambungan yang diberikan oleh pemberiwaralaba. 
5. Adanya dukungan yang berkesinambungan

Dukungan dari pemberi waralaba kepada penerima waralaba secara terusmenerus seperti bimbingan operasional, pelatihan dan promosi.

6. Hak kekayaan Intelektual yang telah terdaftar

Hak kekayaan intelektual yang terkait dengan usaha seperti merek, hakcipta atau paten atau lisensi dan / atau rahasia dagang sudah didaftarkan dan mempunyai sertifikat atau sedang dalam proses pendaftaran diinstansi yang berwenang.

Dalam sistem franchise ada pos-pos biaya yang normal dikeluarkan sebagai berikut: ${ }^{41}$

1. Royalty

Pembayaran oleh pihak franchisee kepada pihak franchisor sebagai imbalan dari pemakaian hak franchise oleh franchisee.Walaupun tidaktertutup kemungkinan pembayaran royalty pada suatu waktu dalam jumlah tertentu yang sebelumnya tidak diketahuinya (sistem lumsump).

2. Franchise fee

Yang dimaksud Franchise fee adalah biaya pembelian hak waralaba yang dikeluarkan oleh pembeli waralaba (franchisee) setelah dinyatakan memenuhi persyaratan sebagai franchisee sesuai kriteria franchisor.Umumnya franchise fee dibayarkan hanya satu kali saja dan akan dikembalikan oleh franchisor kepada franchisee dalam bentuk fasilitas pelatihan awal, dan dukungan set up awal dari outlet pertama yang akan dibuka oleh franchisee. ${ }^{42}$ Franchisee dalam hal ini menerima hak untuk berdagang di bawah nama dan sistem yang sama, pelatihan, serta berbagai keuntungan lainnya. Sama halnya dengan memulai bisnis secara mandiri,franchisee bertanggung jawab untuk semua biaya yang muncul guna memulai usaha ini tetapi kemungkinan mengeluarkan uang lebih rendahkarena kekuatan jaringan yang dimiliki oleh franchisor.

3. Direct Expenses

Biaya langsung yang harus dikeluarkan sehubungan dengan pengembangan bisnis franchise. Misalnya, terhadap pemondokan pihak yang akan menjadi pelatih dan feenya, biaya pelatihan dan biaya pada saatpembukaan.

4. Biaya sewa

\footnotetext{
${ }^{41}$ Munir fuady, op. cit. hal. $346-347$

${ }^{42}$ S. Muharam, Istilah - Istilah Dalam Waralaba, SMfr@ nchise, Oktober, 2002
} 
Ada beberapa franchisor yang menyediakan tempat bisnis, maka dalamhal demikian pihak franchisee harus membayar harga sewa tempat tersebut kepada franchisor agar tidak timbul disputes di kemudian hari.

5. Marketing and advertising fees

Franchisee ikut menanggung beaya dengan menghitungnya, baik secarapersentase dari omzet penjualan ataupun jika ada marketing atau iklantertentu.

6. Assignment fees

Biaya yang harus dibayar oleh pihak franchisee kepada pihak franchisorjika pihak franchisee mengalihkan bisnisnya kepada pihak lain, termasukbisnis yang merupakan objeknya franchise. Oleh pihak franchisor biaya itu dimanfaatkan untuk kepentingan persiapan pembuatan perjanjian penyerahan, pelatihan pemegang franchise yang baru dan sebagainya.

Setiap hubungan bisnis yang ada selalu saja ada faktor kerugian dankeuntungannya. Demikian juga dengan bisnis franchise ada keuntungan dan kerugianyang terjadi di dalamnya. Keuntungan dari bisnis franchise dapat dikemukakansebagai berikut $:^{43}$

1) Diberikannya latihan dan pengarahan yang diberikan oleh franchisor. Latihan awal ini diikuti oleh pengawasan yang berlanjut.

2) Diberikannya bantuan financial dari franchisor. Biaya permulaan tinggi, dan sumber modal dari pengusaha sering terbatas. Bila prospek usaha dianggap suatu resiko yang baik, franchisor sering memberikan dukungan financial kepada franchisee.

3) Diberikannya penggunaan nama perdagangan, produk atau merek yangtelah dikenal secara luas.

Sedangkan kerugian dalam bisnis franchise antara lain sebagai berikut :

1) Adanya program latihan yang dijanjikan oleh franchisor kadangkala jauh dari apa yang diinginkan oleh franchisee.

2) Perincian setiap hari tentang penyelenggaraan perusahaan sering diabaikan.

3) Hanya sedikit sekali kebebasan yang diberikan kepada franchisee untuk menjalankan akal budi mereka sendiri. Mereka mendapatkan diri mereka terikat pada suatu kontrak yang melarang untuk membeli baik peralatan maupun perbekalan dari tempat lain.

\footnotetext{
${ }^{43}$ Richard Burton Simatupang, op. cit, hal. 60 - 61
} 
4) Pada bisnis franchise jarang mempunyai hak untuk menjual perusahaan kepada pihak ketiga tanpa terlebih dahulu menawarkannya kepada franchisor dengan harga yang sama.

Dalam format bisnis waralaba, terdiri dari beberapa unsur yaitu :

\section{Single unit Franchise}

Format yang paling sederhana dan paling banyak digunakan karenakemudahannya. Pewaralaba memberikan hak kepada terwaralaba untukmenjalankan usaha atas nama usahanya, dengan panduan prosedur yangtelah ditetapkan sebelumnya. Terwaralaba hanya diperkenankan untuk menjalankan usahanya pada sebuah cabang / unit yang telah disepakati.

2. Area franchise

Hak waralaba yang diberikan kepada individu atau perusahaan meliputiwilayah geografis yang telah ditentukan dalam perjanjian waralaba (franchise agreement). Pada prakteknya area franchise dapat diberikan target dan dead line berkaitan dengan jumlah outlet yang harus dibuka.

\section{Master Franchise}

Format master franchise memberikan hak pada pemegangnya untukmenjalankan usahanya di sebuah teritori ataupun sebuah Negara danbukan hanya membuka usaha, pemegang hak dapat menjual lisensi kepada sub franchise dengan ketentuan yang telah disepakati. ${ }^{44}$

Pelaksanaan perjanjian waralaba ini dalam Peraturan Pemerintah RI No. 42 Tahun 2007 pada pasal 4 ayat (1) disebutkan bahwa waralaba diselenggarakanberdasarkan perjanjian tertulis antara pemberi waralaba dengan penerima waralabadengan memperhatikan Hukum Indonesia dan pada pasal 4 ayat (2) disebutkan pula dalam hal perjanjian sebagaimana dimaksud pada ayat (1) ditulis dalam bahasa asing, perjanjian tersebut harus diterjemahkan ke dalam bahasa Indonesia. Dengan demikian, apabila pihak pewaralaba pihak asing, sedangkan terwaralaba adalah Indonesia, maka perjanjiannnya terikat pada peraturan Pemerintah No 42 Tahun 2007 tentang waralaba. Sedangkan untuk format perjanjian itu sendiri tidak menyebutkanharus menggunakan akta notaris atau tidak, baik dalam peraturan yang lama maupunperaturan yang baru.

Ketentuan pasal 5 Peraturan Pemerintah No. 42 tahun 2007, perjanjianwaralaba memuat klausula paling sedikit :

\footnotetext{
${ }^{44}$ www.franchise.id.com, 19. 00 WIB tanggal 30 Juli 2013
} 

a. Nama dan alamat para pihak;
b. Jenis hak kekayaan intelektual;
c. Kegiatan usaha;
d. Hak dan kewjiban para pihak;
e. Bantuan, fasilitas, bimbingan operasional, pelatihan, dan pemasaran yang diberikan pemberi waralaba kepada penerima waralaba;
f. Wilayah usaha;
g. Jangka waktu perjanjian;
h. Tata cara pembayaran imbalan;
i. Kepemilikan, perubahan kepemilikan, dan hak ahli waris;
j. Penyelesaian sengketa; dan
k. Tata cara perpanjangan, pengakhiran, dan pemutusan perjanjian;

Selanjutnya dijelaskan pula dalam pasal 6 ayat (1) bahwa dalam perjanjianwaralaba ini dapat memuat klausula pemberian hak bagi penerima waralaba untukmenunjuk penerima waralaba lain dan dalam ayat (2) ditegaskan kembali bahwapenerima waralaba yang diberi hak untuk menunjuk penerima waralaba lain, harus memiliki dan melaksanakan sendiri paling sedikit 1 ( satu ) tempat usaha waralaba.

\section{PENUTUP}

\section{A. Simpulan}

Waralaba merupakan suatu perikatan/perjanjian antara dua pihak. Sebagaiperjanjian dapat dipastikan terikat pada ketentuan dalam Hukum Perdata (KUH Perdata) tentang perjanjian (pasal 1313), sahnya perjanjian (pasal 1320) dan kebebasan berkontrak (pasal 1338).Ada beberapa syarat untuk kontrak yang berlaku umum tetapi di atur di luarpasal 1320 KUH Perdata, yaitu sebagai berikut :

1) Kontrak harus dilakukan dengan itikad baik

2) Kontrak tidak boleh bertentangan dengan kebiasaan yang berlaku

3) Kontrak harus dilakukan berdasarkan asas kepatutan

4) Kontrak tidak boleh melanggar kepentingan umum

Apabila kontrak dilakukan dengan melanggar salah satu dari 4 (empat)prinsip tersebut, maka konsekuensi yuridisnya adalah bahwa kontrak yang demikian tidak sah dan batal demi hukum (null and void) .Dalam Peraturan Pemerintah Nomor 42 Tahun 2007 tentang Waralaba, terdapat beberapa konsep perlindungan hukum terhadap usaha waralaba, 
yaitu:Pasal 3 huruf f yang menyebutkan bahwa waralaba harus merupakan suatu hak kekayaan intelektual yang sudah terdaftar sehingga terdapat kepastian hukum dalam bisinis waralaba, menghilangkan keragu-raguan akan waralaba yang ditawarkan.Kemudian terdapatnya ketentuan yang mengharuskan dibuatnya perjanjian waralaba dalam Bahasa Indonesia .Keharusan pemberi waralaba untuk memberikan prospektus dan profit sebelum membuat perjanjian waralaba harus dimunculkan, sehingga sangat melindungi kepentingan calon penerima waralaba. Adanya aturan ini memberikan ruang bagi calon penerima waralaba untuk terlebih dahulu mempelajari waralaba yang bersangkutan, keharusan untuk mencantumkan klausula minimal dalam perjanjian waralaba, hal ini akan menciptakan keseimbangan posisi para pihak dalam perjanjian sekaligus memberikan perlindungan hukum. Usaha bisnis waralaba sudah bukan merupakan sesuatu hal yang baru lagi, sudah semestinya model usaha seperti demikian memiliki pengaturan yang memadai untuk menunjang perkembangan dunia usaha, dan juga memberikan proteksi bagi pihak-pihak dalam perjanjiannya dan seharusnya juga hukum posifif Indonesia memiliki pengaturan undang-undang untuk penerapan klausula baku dalam hal kontrak bisnis, untuk mencegah maupun melindungi pebisnis skala kecil dan menengah dari kerugian.

\section{DAFTAR PUSTAKA}

\section{A. Buku}

Badruzman, Mariam D. Aneka Hukum Bisnis, Bandung, Alumni, 1994.

Dipo, Handowo. Sukses Usaha Memperoleh Dana, Dengan Konsentrasi Modal Ventura, Jakarta, Grafiti Press. 1993

Fuady Munir, Hukum Kontrak (Dari Sudut Pandang Hukum Bisnis), Bandung, Citra Aditya Bakti, 2001.

Guritno, T. 1992. Kamus Ekonomi Bisnis Perbankan, Cetakan I, GajahMadaUniversity Press. Yogyakarta.

Harjowidigno, Rooseno. Aspek-aspek Hukum tentang Franchising, Seminar Ikadin, Surabaya. 1993.

Meliala, A. Qiram Syamsudin. Pokok-pokok Hukum Perjanjian Beserta Perkembangannya, Liberty, Yogyakarta. 1985.

Mendelsohn, Martin. Franchising: Petunjuk Praktis bagi Franchisor dan Franchisee, PT. Pustaka Binaman Perssindo. 1997.

Muhammad, Abdul Kadir. Hukum Perikatan, Citra Aditya Bakti, Bandung. 1992.

Patrik, Purwahid. Dasar-dasar Hukum Perikatan (Perikatan yang lahir dari perjanjian dan dari Undang-Undang), Mandar Maju, Bandung. 1994.

Projodikoro, R. Wiryono. Asas-asas Hukum Perjanjian, Sumur, Bandung. 1993. 
Sembel Roy. dan Ferdiansyah Tedy, 2002. Tujuh Jurus Pendanaan di Tahun Kuda Air, USAHAWAN No. 03 Th. XXXI. Jakarta.

Setiawan, R. 1994. Pokok-pokok Hukum Perikatan, Bina Cipta, Bandung.

Soekanto, Soerjono dan Sri Mamudji, Penelitian Hukum Normatif, Suatu Tinjauan Singkat, Jakarta. Raja Grafindo Persada. 1995.

Soekanto, Soerjono. 1986. Pengantar Penelitian Hukum, UI Press, Jakarta.

Subekti, R, Hukum Perjanjian. Cetakan ke-16. PT. Intermasa: Jakarta. 1996

Widjaya, Gunawan. Lisensi Atau Waralaba, Suatu Panduan Praktis, Jakarta : Raja Grafindo Persada. 2002

\section{B. Artikel/Makalah/Majalah}

Harjowidigdo, Rooseno., Beberapa Aspek Hukum Franchising, dalam "Seminar Sehari Aspek-aspek Hukum Tentang Franchising”, diselenggarakan oleh IKADIN Cabang Surabaya, Surabaya 23 Oktober 1993.

Sembel, Roy - Tedy Ferdiansyah, Tujuh Jurus Pendanaan Di Tahun Kuda Air, Jakarta : USAHAWAN No. 03 Th. XXXI. 2002.

\section{Peraturan PerUndang-undangan}

Kitab Undang-undang Hukum Perdata

Peraturan Pemerintah No 42 Tahun 2007 tentang Waralaba,

Peraturan Pemerintah RI No. 16 Tahun 1997 tanggal 18 Juni 1997 tentang Waralaba

Peraturan Menteri Perdagangan Republik Indonesia Nomor: 31/MDAG/PER/8/2008 tentang Penyelenggaraan Waralaba.

Peraturan Menteri Perindustrian dan Perdagangan No. 259/MPP/KEP/7/1997 tentang Ketentuan Tata Cara Pelaksanaan Pendaftaran Usaha Waralaba.

Lampiran Keputusan Menteri Perindustrian Dan Perdagangan No. 259/MPP/KEP/7/1997 tentang Ketentuan Dan Tata Cara Pelaksanaan Pendaftaran Usaha Waralaba.

\section{Internet}

gwww.franchise.com

www.santoslolowang.com 